\title{
ЭКОНОМИЧЕСКОЕ РАЗВИТИЕ СИБИРИ КАК РЕЗУЛЬТАТ ГОСУДАРСТВЕННОЙ СТРАТЕГИИ, НАПРАВЛЕННОЙ НА ИНДУСТРИАЛЬНУЮ МОДЕРНИЗАЦИЮ СССР
}

Аннотация. В статье анализируются проблемы экономического развития Сибири в качестве результата государственной стратегии, направленной на индустриальную модернизацию СССР. Кроме того, в статье показана роль Сибирского региона в социально-экономическом развитии Советского государства.

Автор высоко оценивает значение экономики Сибири для всей страны, подчеркивает, что развитие производительных сил на восток было напрямую связано с индустриальной модернизацией в СССР, без которой невозможно было выжить в современном мире и сохранить независимость государства. В этой ситуации большое значение имели территории и природные ресурсы Сибирского региона, обозначавшегося в качестве тылового района государства, в котором можно создавать предприятия различных отраслей военно-оборонной промышленности.

В статье также определены в общих чертах этапы движения производительных сил СССР в восточную сторону. Вначале это была реализация Урало-Кузнецкой индустриальной программы, затем в послевоенные годы Ангаро-Енисейской, Западно-Сибирской нефтегазовой и строительство БАМ. Для обеспечения транспортом данных индустриальных программ активно развивалось транспортное строительство. В результате исследования сделан вывод, что экономическое развитие Сибири в советский период происходило в соответствии со стратегическими целями государственной политики. 
Ключевые слова. Сибирь, регион, экономическое развитие, государственная стратегия, индустриальная модернизация.

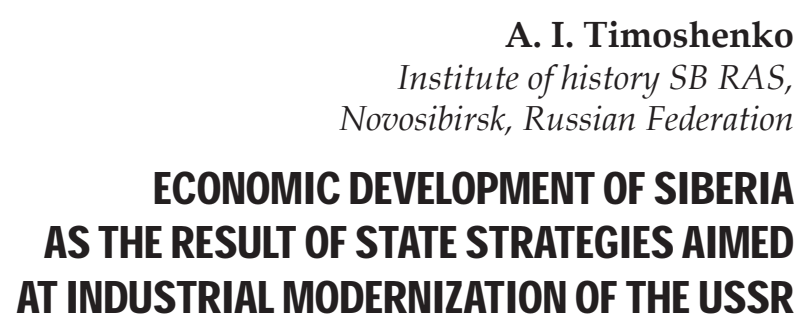

Abstract. The article examines problems of economic development of Siberia as a result of state strategies aimed at industrial modernization in the USSR. In addition, the article shows the role of the Siberian region in the socio-economic development of the Soviet state.

The author highly appreciates the importance of the Siberian economy for the whole country, emphasizes that the development of productive forces in the East was directly connected with industrial modernization in the USSR, without which it was impossible to survive in the modern world and preserve the independence of the state. In this situation, territories and natural resources of the Siberian region were of great importance because it was designated as the rear territory of the state, in which it was possible to create enterprises of various branches of the military-defense industry.

The article also defines in general terms the stages of the movement of the productive forces of the USSR to the East. First, it was the implementation of the UralKuznetsk industrial program, then, in the postwar years - Angaro-Yenisei, West Siberian oil and gas programs, and the construction of BAM. Transport construction is actively developing to ensure these transport industrial programs. The study showed that the economic development of Siberia in the Soviet period took place in accordance with the strategic goals of state policy.

Keywords. Siberia, the region, economic development, state strategy, industrial modernization. 
Экономическое развитие Сибири ${ }^{1}$ в советский период было напрямую связано с индустриальной модернизацией. Советское правительство рассматривало индустриализацию в качестве решающего фактора выживания политического строя и в целом государства. В этой ситуации важнейшую роль предстояло сыграть пространству и природным ресурсам Сибири. Активизация их использования в экономическом развитии Российского государства стала проявляться ещё в начале XX века с вводом в эксплуатацию Транссиба, который создавал возможности, как для роста экономики, так и для заселения восточных регионов русскоязычными людьми.

Советская власть унаследовала данное отношение к социально-экономическому развитию Урала, Сибири и Дальнего Востока. Планы социалистической индустриальной модернизации включали в себя как заселение, так и экономическое развитие восточных регионов, в том числе не только западных и южных территорий, примыкающих к Транссибу, но и северных, богатых природными и минерально-сырьевыми ресурсами, необходимыми для роста экономики страны. Поэтому в государственной модернизационной стратегии восток занимал одно из главных мест.

Индустриальное развитие конкретно Сибири в 1930-е гг. рассматривалось как поэтапное, продвигающееся с запада на восток и охватывающее всё более новые территории региона. Уже начало реализации данных стратегических замыслов внесло большие изменения в развитие экономики. В Сибири в годы первых предвоенных пятилеток наблюдался резкий рост городов и городского населения, создавались целые промышленные районы и крупные производственные комплексы. В результате в регионе создавалась индустриальная культура производства и жизнедеятельно-

1 Под Сибирью в статье обозначается азиатская часть России от восточных отрогов Урала до Тихого океана.

2018. T. 19, № 1. C. 91-118 
сти населения. Необходимо отметить, что в Сибири индустриализация начиналась с создания базовых отраслей экономики: тяжелой промышленности, военно-оборонных производств, транспортных и энергетических объектов, что являлось определяющим фактором для соответствующих социально-демографических и социокультурных изменений в регионе.

Первой индустриальной программой в Сибири стал Урало-Кузнецкий проект, который реализовывался в конце 1920-х и 1930-е гг. В результате создания Урало-Кузнецкого комбината (УКК) достигалась стратегическая цель, связанная с обеспечением индустриальной основы развития экономики Урала и Сибири, превращением огромного региона в индустриально развитый. В 1940 г. по сравнению с 1928 г. показатели валовой продукции крупной промышленности Кузбасса выросли в 23 раза, в том числе угольной - в 8,6 раза, черной металлургии - в 200 раз, производства электроэнергии - в 77,5 раза [6, с. 13-19, 24, 30].

Стратегическая роль Урало-Кузнецкой программы состояла в том, чтобы обеспечить Урал и Сибирь новейшей промышленной и аграрной техникой в достаточном количестве, а для этого наладить в регионах не только выплавку черных и цветных металлов, но и создать крупные машиностроительные производства. Кроме того, советское правительство рассчитывало, что реализация проекта изменит экономическую ситуацию, демографическую структуру и социально-бытовые условия жизни населения обширного Урало-Сибирского региона. Модель Урало-Кузнецкого комбината вполне вписывалась в общую концепцию хозяйственного развития СССР, основанную на идее социалистического обобществления и создания в основном крупной промышленности в процессе индустриализации страны. По своим масштабам и замыслу Урало-Кузнецкая программа соответствовала политическим амбициям советского руководства в направлении 
социально-экономического переустройства общества. В ней также отражалось стремление государственного управления доказать преимущества социалистического строя, в первую очередь в экономическом развитии.

В 1932 г. Магнитогорский и Кузнецкий комбинаты-первенцы УКК дали свой первый металл. В результате стали активно разрабатываться новые техникоэкономические проекты. Большинство из них ориентировалось на развитие машиностроения особенно сельскохозяйственного. В этот период в Сибири формировалось два центра сельскохозяйственного машиностроения, расположенные в городах Омске и Новосибирске. Переход к обобществленным хозяйствам в сельскохозяйственной сфере придавал проблеме особое значение. Экономисты и плановики высказывали идеи создания агрокомбинатов на базе механизации основных производственных процессов. Поэтому нужно было большое количество высокопроизводительных сельскохозяйственных машин.

К 1937 г. почти 3/4 основных производственных фондов крупной промышленности Сибири в связи с созданием Урало-Кузнецкого комбината приходилось на Западную Сибирь. Однако и в Восточной Сибири за годы первых пятилеток происходило крупное индустриальное строительство. В 1929 г. в Иркутске на базе мелких мастерских началось сооружение крупнейшего в Сибири машиностроительного завода им. Куйбышева по производству машин и оборудования для золотодобывающей промышленности. Уже в августе 1930 г. завод выпустил первый в СССР бур типа «Эмпайр», а в 1931 г. изготовил уже 157 комплектов таких буров, 396 шахтных вагонеток и другое оборудование. В 1932 г. завод приступил к производству драг по отечественным проектам. В Красноярске строился завод тяжелого машиностроения. В крупные предприятия по производству и ремонту оборудования для золотопромышленности и угольных шахт превратились за2018. T. 19, № 1. C. 91-118 
воды группы «Металлист» в Благовещенске и Владивостоке. Резко возрос объем продукции металлообработки в Читинской области, Хабаровском крае, Бурятской АССР [11, с. 168].

В индустриальном освоении Сибири и Дальнего Востока, особенно в разработке месторождений полезных ископаемых, находящихся в труднодоступных в транспортном отношении местах, значительную роль сыграла система ГУЛАГа. В 1930-е гг. заключенные лагерей и колоний, а также так называемые спецпереселенцы являлись важной частью трудовых ресурсов СССР. Сибирское и Дальневосточное управления лагерей особого назначения ОГПУ, а затем НКВД СССР, были созданы по решению СНК СССР в 1929 г. Вначале подведомственные им лагеря выполняли роль изоляторов для «социально-чуждых», «деклассированных» и криминальных элементов, а затем в процессе форсированного выполнения пятилетних планов превратились в своеобразные экономические центры, обладающие дешевой рабочей силой и способные реализовывать стратегические проекты по освоению восточных регионов СССР, богатых природными ресурсами.

Подневольный труд активно использовался на индустриальных новостройках Кузбасса. Сюда после принятия в августе 1930 г. постановления СНК РСФСР «О мероприятиях по проведению спецколонизации в Северном и Сибирском краях и Уральской области» отправлялись тысячи раскулаченных крестьян и членов их семей. В Кузбасс, в отличие от других районов Сибири, пытались ссылать наиболее трудоспособных крестьян и концентрировать их на крупных и трудоемких стройках, не распыляя трудовой контингент по мелким предприятиям. В качестве основных потребителей дешевой рабочей силы выступили управление «Кузнецкстрой», тресты «Востокуголь» и «Цветметзолото». Спецпереселенцы в значительной степени пополнили ряды строителей Кузнецкого металлурги- 
ческого комбината. Большая часть данного кадрового контингента была задействована также в угледобыче и в лесной промышленности. Причем для работы в шахтах направлялись семьи, имеющие молодых работоспособных мужчин. В итоге только за 1931 г. на новостройки и предприятия Кузбасса было направлено свыше 50 тыс. спецпереселенцев из Европейской части CCCP [1, с. 38].

По планам индустриализации Сибири, которые разрабатывались в 1930-е гг., следующей после Урало-Кузнецкой программы намечалась Ангаро-Енисейская, но война затормозила реализацию данных намерений. К ним удалось вернуться только через несколько лет после победы над врагом. Реализация Ангаро-Енисейской программы началась с энергетического строительства. Вначале на Ангаре, затем на Енисее был построен целый ряд крупнейших в мире гидроэлектростанций, которые послужили основой для создания энергоемких производств в Восточной Сибири.

Например, в годы семилетки в Ангаро-Енисейском регионе сооружалось сразу три крупных завода по выплавке «крылатого» металла - алюминия. 10 февраля 1962 г. первую продукцию выдал Иркутский алюминиевый завод, весной 1964 г. начал действовать Красноярский, который уже в 1965 г. вышел на проектную мощность и выпустил сверх планового задания сотни тонн алюминия высшего качества, сэкономив при этом свыше 30 млн кВт-часов электроэнергии, десятки тонн глинозема, криолита и другого сырья. Сибирский алюминий с маркой Братского алюминиевого завода стал поступать в промышленность СССР с июля 1966 г. Глубокой реконструкции подверглись Новокузнецкий алюминиевый завод, Беловский цинковый, Новосибирский оловокомбинат. Новые производственные мощности создавались на Норильском горно-металлургическом комбинате. Основные производственные 2018. T. 19, № 1. C. 91-118 
фонды цветной металлургии Сибири выросли почти в 2 раза, а производство продукции в 1,7 раза. Восточная Сибирь по производству цветных металлов значительно опережала Западную. В целом в регионе производство валовой продукции в 1945-1965 гг. выросло с 173,8 до 1056,4 млн руб. [12, с. 308].

В послевоенные годы дальнейшее развитие получило в Сибири машиностроение, обеспечивающее технический прогресс во всех отраслях народного хозяйства. Объём производства машиностроительной продукции только в Кузбассе с 1959 по 1965 г. увеличился в 1,9 раза. Значительная часть машиностроения региона специализировалась на производстве машин и оборудования для угольной промышленности. В 1950-е гг. производственное оборудование большинства предприятий значительно обновилось. Их станочный парк пополнился кузнечнопрессовым и литейным оборудованием, специальными автоматическими и полуавтоматическими конвейерными линиями и станками, которые по своим эксплуатационным качествам были намного производительнее ранее применяемого металлорежущего оборудования. А это привело к изменению технологии обработки металла в сторону эффективности и сокращения времени. Всё более широкое распространение получала так называемая групповая обработка универсальных деталей, которая значительно ускоряла процессы сборки машин и механизмов, влияла на снижение в целом их себестоимости. Углубились процессы специализации и кооперирования машиностроительных предприятий. Большое значение приобрела борьба за качество продукции, снижение её себестоимости, металлоемкости. Производимые в Сибири шахтное оборудование, машины и механизмы использовались не только в СССР, но и покупались зарубежными предприятиями, экспонировались на международных выставках, где отмечались дипломами и медалями. 
В 1960-1980-е гг. в Сибири активно развивалось транспортное строительство, в том числе и новых для региона видов транспортировки грузов. Особое внимание обращалось на районы интенсивного промышленного освоения. Наиболее масштабное дорожное строительство осуществлялось в нефтегазовых районах Западной Сибири. Здесь в 1960-е гг. развернулось строительство автодорог преимущественно с твердым покрытием, самых современных аэродромов со специальными взлетно-посадочными полосами для приёма большегрузных самолётов.

Впервые в истории Сибирского региона началось строительство трубопроводов. От крупных сибирских месторождений на юг и запад потянулись многокилометровые магистральные нефтегазопроводы. Первый нефтепровод Шаим - Тюмень протяженностью 410 км был введен в эксплуатацию 3 ноября 1965 г. Самые мощные трубопроводы для транспортировки нефти и газа из северных районов Западной Сибири сооружались в 1970-е годы. В этот период стали активно использоваться новые высокопроизводительные технологии строительства, новая техника, трубы большого диаметра, что позволило уже в годы девятой пятилетки ввести в эксплуатацию 5,4 тыс. км магистральных нефте и газопроводов, которые перекачивали из Сибири на далекие расстояния миллионы тонн углеводородов. Строительство самых протяженных из них Медвежье - Урал - Центр, Уренгой - Центр, Уренгой - Помары - Ужгород оценивалось в стране и в мире в качестве крупнейших национальных достижений $[8$, с. 57]

Основным видом транспорта в Сибири по-прежнему оставался железнодорожный. Он осуществлял главную массу грузовых и пассажирских перевозок. К началу 1960-х гг. масштабная реконструкция на базе электрификации существующих железных дорог позволила увеличить их провозную способность более чем в 2018. T. 19, № 1. C. 91-118 
два раза и сосредоточить внимание на строительстве новых линий, которые также, чаще всего, были связаны с районами нового промышленного освоения. Важнейшими новостройками 1970-1980-х гг. стали линии к богатым месторождениям нефти и газа на севере Западной Сибири Тюмень - Сургут - Нижневартовск, Сургут - Новый Уренгой - Ямбург и др. [3, с. 547].

В 1974 г. началось строительство легендарной Байкало-Амурской магистрали (БАМ). Продолжились начинания 1930-1940-х гг. по проектированию и сооружению первых объектов магистрали. На новой научно-технической и экономической основе строительство железной дороги рассматривалось в самом широком смысле этого понимания, как проект, не только сугубо транспортный, но и пионерный, рассчитанный на обживание и хозяйственное освоение сурового по природно-климатическим условиям района. Предполагалось, что со временем программа строительства железнодорожной магистрали на северо-востоке страны трансформируется в масштабный социально-экономический проект по развитию и преобразованию огромной территории, богатой природными ресурсами и представляющей значительный геополитический интерес на восточных рубежах государства.

В планах социально-экономического развития страны обозначилась новая грандиозная программа. Сама железнодорожная трасса протяженностью свыше 3000 км должна была пройти от Усть-Кута до Комсомольска-на-Амуре по районам со сложнейшими природно-климатическими условиями, пересечь 11 полноводных рек, и 7 горных хребтов. Более 1000 км дороги проектировалось провести по районам вечной мерзлоты, планировалось построить 136 мостов длиной от 100 м до 1,5 км каждый. Всего в рамках проекта предполагалось построить 3200 искусственных сооружений, в среднем примерно по одному на километр пути. Причем многие из них уникальные, например, 
тоннели через неприступные горные хребты - Ceверо-Муйский длиной 15 км, Байкальский - 6,7 км, мост через Амур у Комсомольска-на-Амуре протяженностью 1,5 км и мост через Зейское водохранилище с пролетами в 134 м и мощными высокими опорами. На трассе было запланировано строительство 200 с лишним станций и разъездов, около 60 городов и поселков [3, с. 156-157].

Такой грандиозный проект было намечено осуществить в очень короткие сроки, к началу 1980-х гг. Ориентировочный объем капиталовложений был определен примерно в 1500 млн руб. Намечался специальный план мероприятий по развитию мощной базы стройиндустрии в прилегающих районах: расширялись и реконструировались предприятия по производству строительных материалов в пос. Шимановском, Тайшете, Нижнеудинске, Братске, предполагалось строительство новых в Усть-Илимске, Усть-Куте в Комсомольске на Амуре и др. Практически заново создавалась энергетическая база региона.

Стоит отметить, что в годы «холодной войны» активно развивалась военно-оборонная промышленность Сибири. Дело в том, что регион высоко оценивался как тыловой район СССР, удаленный от границ и богатый разнообразными природными ресурсами. В послевоенные годы военно-оборонная промышленность региона, пережив трудности конверсии, продолжила набирать темпы развития. Новосибирск оставался крупнейшим центром производства боеприпасов по самой широкой номенклатуре. На заводе им. Чкалова продолжился выпуск совершенной по своему времени военной авиационной техники. В 1948 г. завод получил правительственное задание наладить серийный выпуск реактивных летательных аппаратов и вскоре приступил к выпуску крупных серий самолетов Миг-15, Миг-17 и Миг-19. Истребители Миг-19 обеспечивались новейшей инфракрасной системой перехвата, позво2018. T. 19, № 1. C. 91-118 
лявшей во взаимодействии с наземными средствами наведения обнаруживать и пеленговать самолеты противника на расстоянии до 20 км. Самолеты этой марки были высшим достижением реактивной боевой техники того времени.

С конца 1955 г. на заводе им. Чкалова началось производство самолетов-перехватчиков типа СУ. В короткие сроки коллектив завода освоил серийное производство самолетов СУ-9, которые стали занимать ведущие места в Военно-воздушных силах СССР по своим летно-тактическим характеристикам. На них устанавливались мировые рекорды по скорости и высоте полета. На заводе осваивалось также серийное производство новейших истребителей-перехватчиков ЯК-28, которые, как и самолеты марки СУ, по своим летно-тактическим данным опережали лучшие образцы зарубежной авиационной техники. В едином комплексе в Новосибирске действовали производственные цеха, научно-исследовательские и проектные организации. За все годы производственной деятельности в советский период завод им. Чкалова освоил производство 27 типов самолетов, передал в Вооруженные Силы СССР 26700 боевых машин, в том числе в 1946-1965 гг. более 10000 реактивных самолётов [13, с. 150-151].

Вторым крупным центром военно-оборонной промышленности в Сибири являлся Омск. Здесь находилось три завода авиационной промышленности, несколько предприятий по производству боеприпасов, военной электроники и радиотехники. Сформировавшийся в годы Великой Отечественной войны Омский авиационный завод (№ 166) производил самолеты типа $\mathrm{AH}$, запасные части для авиационной техники. Моторостроительный завод им. Баранова выпускал двигатели для авиационной и ракетной техники и запасные части к ним. Завод № 20 изготавливал на специально созданном производстве ракетную технику, агрегаты для ракетных двигателей и другую аппаратуру. 
В Красноярске на машиностроительном заводе им. В. И. Ленина, знаменитом индустриальном детище первых пятилеток «Красмаше», приступили кпроизводству сложнейшей ракетно-космической техники. Завод до 1941 г. выпускал оборудование для угольной, золотодобывающей и нефтяной промышленности: шахтные подъемные машины, лебедки, проходческие комбайны, врубовые машины и вагонетки. С началом войны перешел в распоряжение Наркомата вооружения. В него влились эвакуированные из западных районов страны Коломенский завод им. Ворошилова, частично Ленинградские заводы «Арсенал» и «Большевик», Калужские и Сталинградские машиностроительные заводы. Основной продукцией объединенного завода стали автоматические зенитные пушки. Первый эшелон пушек из Красноярска на фронт отправился 15 ноября 1941 г. Всего за годы войны «Красмаш» произвел 26 тыс. пушек различных систем, более 5 тыс. минометов, 220 тыс. крупных авиабомб, 3500 морских мин [13, с. 152].

В послевоенные годы на «Красмаше» продолжалось серийное производство автоматических зенитных пушек. С 1958 г. по специальным решениям правительства началась реконструкция завода с целью производства здесь новой ракетно-космической техники. С 1959 по 1965 гг. производственные площади завода увеличились втрое, численность работающих - вдвое, а объем валовой продукции - в 3,3 раза. В результате организовано высокотехнологическое производство ракетно-космической техники, налажен выпуск первых советских баллистических ракет. С 1959 г. «Красмаш» работал в едином комплексе с ОКБ-10 (НПО прикладной механики, Красноярск-26) в направлении проведения опытно-конструкторских работ и изготовления ракетно-космической техники. К 1964 г. в Красноярске освоено производство ракет-носителей для выведения на круговые орбиты легких спутников, позже баллистических ракет морского базирования. 
Сибирь ещё в годы войны рассматривалась в качестве местонахождения предприятий ядерного комплекса СССР. В конце 1940-х гг. здесь развернулось строительство двух крупных сибирских предприятий атомной промышленности: в Новосибирске завода № 250 (ныне Новосибирский завод химконцентратов) и Сибирского химического комбината №816 около Томска (Томск-7, г. Северск). После их сооружения завод Химконцентратов осуществлял переработку урановой руды, выпускал топливо для реакторов, нарабатывающих оружейный плутоний, топливные стержни и тепловыделяющие сборки. А Сибирский химический комбинат, на возведенных пяти атомных реакторах и пяти заводах, серийно производил делящиеся материалы и изготовлял из них элементы и в целом ядерные заряды различной модификации. Всего на этих двух предприятиях действовало 8 самых крупных в СССР из 13 имеющихся атомных ректоров по выработке оружейного плутония. За все годы их производственной деятельности они произвели до 80 \% плутония в стране и вместе с другими предприятиями военно-оборонного комплекса в Сибири более 50 \% оружейного урана [13, с. 153-154].

Несколько позже в Сибири построены ещё три предприятия по обогащению урана и изготовлению его оружейной формы. В 1950-1964 г. на берегу Енисея в 64 км от Красноярска в толще гранитных скал на глубине 200-250 км от поверхности сооружался Красноярский горно-химический комбинат (Красноярск-26, г. Железногорск). В 1957 г. выдал первую продукцию - обогащенный гексафторид урана, служивший сырьем для других атомных предприятий, Ангарский электролизно-химический комбинат (г. Ангарск Иркутской области). 30 октября 1962 г. в 150 км восточнее Красноярска начал работу Электрохимический комбинат №825, известный как Красноярск-45 (г. Зеленогорск). 
Все эти предприятия атомной промышленности нуждались в большом количестве электроэнергии, которую могли дать крупнейшие ГЭС Сибири, построенные на Ангаре и Енисее. Необходимость снабжения электроэнергией секретных атомных производств в Красноярском крае также явилась одной из весомых причин для активизации изучения в 1950-1960-е гг. проблем, связанных с формированием Канско-Ачинского топливно-энергетического комплекса. Для получения 1 кг высокообогащенного урана требовалось 175-200 кг руды и около 600000 квт. часов электроэнергии [13, с. 154].

В Сибири наилучшим образом сочетались различные возможности как для развития и совершенствования существующих предприятий военно-промышленного комплекса Сибири, так и для создания новых производств военно-стратегического назначения. Построенные в 1950-1960-е гг. крупнейшие в мире энергетические объекты могли обеспечивать электроэнергией предприятия атомного производства. Сибирские реки давали огромную массу воды низкой температуры и высокой степени чистоты для охлаждения атомных реакторов. Пространства региона, находившиеся в центре страны и покрытые в основном таёжными лесами, являлись малоуязвимыми для вражеского нападения и с суши, и с воздуха. А в условиях закрытости страны и умения служб государственной безопасности охранять её секреты, сибирские предприятия атомного комплекса долгие годы являлись недосягаемыми и для иностранных разведок.

Возрастание роли Сибири в экономического развитии Советского государства происходило благодаря крупным капитальным вложениям в развитие экономики региона, которые требовались в условиях качественного преобразования производительных сил на новой технической и технологической основе. Сибирская индустрия в этот период развивалась за счет эк2018. T. 19, № 1. C. 91-118 
стенсивных факторов и своих значительных природных возможностей, а также за счет нарастающих темпов интенсификации производства.

Комплексная механизация и автоматизация производственных процессов в промышленности Сибири внедрялась как при реконструкции и модернизации промышленных предприятий, так и при техническом оснащении вновь построенных заводов и фабрик. В 1960-1980-е гг. в Сибири и на Дальнем Востоке вводились в строй крупные промышленные объекты, становившиеся в короткие сроки флагманами в своих отраслях не только по масштабам выпуска соответствующих видов продукции, но и по своему техническому и технологическому уровню. В проектах строительства новых предприятий предусматривались более совершенные и высокоэффективные технические и технологические решения, при которых деятельность человека чаще всего сводилась к контрольным функциям и регулировке автоматически происходящих производственных процессов.

Примером практически полной механизации и автоматизации производства среди горнорудных предприятий Сибири в 1960-1970-е гг. может служить Коршуновский горно-обогатительный комбинат (КГОК), на котором производительность труда была самой высокой в отрасли. Она достигала почти 80 т горной массы на одного рабочего за смену. При этом руда добывалась открытым способом с использованием высокопроизводительных горных машин и доставлялась на фабрику в мощных думпкарах локомотивами специального горнопромышленного назначения.

При проектировании и строительстве обогатительной фабрики КГОКа специалисты учли местные природные условия. Производственные объекты расположили на склоне горы в ступенчатом порядке. При проектировании и строительстве обогатительной фабрики специалисты учли местные природные 
условия. Производственные объекты расположили на склоне горы в ступенчатом порядке. Железная руда проходила все стадии обогащения, поступая из одного отделения в другое под тяжестью собственного веса. При изготовлении железнорудного концентрата из руды использовалась технология так называемого мокрого электромагнитного обогащения, осуществляемого с помощью автоматики и телемеханики. Ручной труд при этом полностью исключался. Коршуновский обогатительный комбинат ежегодно перерабатывал 12 млн т руды и производил до 5 млн т концентрата для металлургических заводов Сибири [7, с. 161].

Поступательное техническое и технологическое совершенствование производственных процессов позволило Коршуновскому ГОКу быть самым передовым в отрасли по росту производительности труда и достижению полной механизации основного производства. От выполнения мероприятий плана внедрения новой техники в 1966-1980 гг. суммарный экономический эффект составил около 5 млн руб. Техническое перевооружение, совершенствование технологии и повышение качества работ позволили предприятию превысить проектные показатели по добыче и переработке руды на 15 \%, по производству товарного концентрата на 7 \%. При этом численность персонала по сравнению с проектной сократилась почти на 500 человек [2, с. 105-106].

Благодаря применению новейшего оборудования, высокой степени механизации и автоматизации производственных процессов обеспечивалась комплексная переработка нефелинов на Ачинском глиноземном комбинате, что позволяло значительно снижать себестоимость сырья для алюминиевой промышленности Сибири по сравнению с продукцией других аналогичных заводов страны. На крупнейших в СССР Братском и Красноярском алюминиевых заводах действовали мощные электролизеры с полной механизацией пода2018. T. 19, № 1. C. 91-118 
чи в ванну глинозема, криолита, анодной массы. Автоматизация электрического и температурного режима электролиза алюминия, коренным образом улучшила санитарно-гигиенические условия труда металлургов.

В 1964 г. введена в эксплуатацию первая доменная печь Западно-Сибирского металлургического комбината. На предприятии полного цикла выплавлялся чугун из железнорудного концентрата, производилась сталь в кислородных конвертерах большой единичной мощности, велась горячая прокатка на непрерывных прокатных станах, оснащенных установками термоупрочнения. В 1980 г. комбинат произвел 8 млн т стали и 4,9 млн т проката. В целом доля Сибири в общероссийском производстве стали увеличилась с 13,2% в 1960 г. до 15,6 \% в 1980. Максимальный уровень производства сибирского металла был достигнут в 1988 г. - 14,2 млн т стали [4, с. 355].

В 1960-1980-е гг. в угледобывающей промышленности Сибири быстрыми темпами росла доля открытой добычи угля, более механизированной по сравнению с подземной. Но самый ценный коксующийся уголь добывался в Кузбассе в шахтах. Поэтому, несмотря на преимущества открытой добычи, приходилось искать пути повышения эффективности и подземной выемки угля. В шахтах Кузбасса в годы 11-й пятилетки значительно обновилась горная техника, в половине забоев заменены крепи на более современные и надежные, внедрены новые высокопроизводительные скоростные конвейеры для транспортировки угля и породы. В результате общий уровень механизации подготовительных работ превысил 60 \% , в том числе на очистных работах он достигал 80 \%. Весьма высокий показатель в сравнении с другими шахтами СССР. В Кузбассе появились автоматизированные шахты с минимальным использованием тяжелого ручного труда. Например, в шахте «Распадская» не стало традиционной рельсовой 
откатки, весь добытый уголь от забоя до выхода на поверхность переносился мощными конвейерами. В лавах были установлены механизированные комплексы по добыче угля, которые осуществляли до 90 \% подземных выработок. Производительность труда на шахте почти втрое превышала среднюю по отрасли.

Ещё быстрее росла механизация открытых разработок угольных месторождений. Среди предприятий такого типа в Сибири выделялись разрезы КанскоАчинского бассейна. Здесь в связи с формированием масштабного топливно-энергетического комплекса в 1980-е гг. проводилась большая работа по техническому перевооружению угледобывающих предприятий. На разрезах бассейна отрабатывались высокопроизводительные технологические схемы с помощью уникальных образцов горных машин: мощных роторных экскаваторов с высокой степенью концентрации добычных работ на одну единицу техники. Вскрышные работы осуществлялись драглайнами с размером ковша в сто кубометров.

В Канско-Ачинском угольном бассейне, находящемся в благоприятных природно-климатических и экономико-географических условиях Сибири, в конце 1950-х гг. было открыто крупнейшее в мире Березовское месторождение каменного угля с толщиной пластов до 70 м. Разведочные работы показали его совершенную уникальность. Неглубокое залегание мощнейших пластов позволяло вести добычу наиболее эффективным открытым способом в больших размерах до 1 млн т в год. К 1965 г. в Канско-Ачинском бассейне функционировали только два относительно крупных разреза Назаровский и Ирша-Бородинский с перспективой увеличения их мощности в дальнейшем примерно в два раза, принято решение о строительстве Назаровской ГРЭС с проектной мощностью в 1,4 млн кВт. Строительство Березовского разреза и Березовской ГРЭС отложилось до 1980-х гг. [10, с. 72-73]. 
Проектанты угледобывающих и энергетических предприятий столкнулись с необходимостью решения целого ряда сложнейших технических и экологических проблем. Под давлением различных факторов формирование крупнейшего в мире топливно-энергетического комплекса по намечавшейся в 1950-е гг. схеме не осуществилось. Но те предприятия, которые построены в Канско-Ачинском бассейне, внесли весомый вклад в социально-экономическое развитие Сибири. Энергия, полученная из канско-ачинского угля, активно использовалась не только в Красноярском крае, но и в Кемеровской и Иркутской областях, Алтайском крае. Ею питались крупнейшие предприятия военно-оборонного комплекса Сибири, входившие в систему атомной промышленности СССР.

В результате предприятия, расположенные в Канско-Ачинском бассейне, значительно обогнали Кузбасс по темпам роста производительности труда и объёмам добытого угля. Здесь в 1960 г. добыто 8,4 млн т топлива, в 1970 г. - 18,4 млн, а в 1980 г. - 41,4 млн т. В 1975 г. себестоимость добычи угля в Канско-Ачинском бассейне составляла в 5 раз меньшую величину, чем в Кузбассе и в 10 раз чем в Донбассе. Всего в 1980 г. на всех угольных месторождениях Сибири было добыто 228 млн т угля или 32 \% от всесоюзной добычи [8, с. 66-67].

Достаточно высокими темпами научно-технический прогресс развивался на предприятиях машиностроения. Вместе с тем, и сами эти предприятия создавали продукцию, обеспечивающую техническое и технологическое совершенствование практически всех отраслей народного хозяйства. Сибирские машиностроители выпускали $1 / 4$ часть союзного выпуска литейного оборудования, 12 \% энергетических машин, более 13 \% технологического оборудования для лесной и деревообрабатывающей промышленности. В Сибири производились уникальные многотонные электродуговые сталеплавильные печи, турбо и гидрогенерато2018, vol. 19, no. 1, pp. 91-118 
ры мощностью до 1 млн кВт и более, станки-автоматы и полуавтоматы, универсальные горизонтально-расточные станки с программным управлением, мощные гидропрессы, тракторы, комбайны и другие сельхозмашины. Всё это являлось крайне востребованным в народном хозяйстве СССР и в том числе на предприятиях Сибирского региона.

На переднем крае научно-технического прогресса всегда находились предприятия военно-оборонного комплекса СССР. В Сибири в послевоенные годы наивысшее развитие получили производства, связанные с атомной промышленностью и ракетно-ядерными вооружениями, которые изначально создавались на основе самых современных научных и технических достижений. 2 июня 1964 г. сибирская военно-оборонная промышленность пополнилась новым предприятием по обогащению урана Красноярским электротехническим заводом, размещавшимся в закрытом городе Красноярск-45 (ныне Зеленогорск). На этом заводе при помощи газовых центрифуг использовалась новая высокопроизводительная технология обогащения урана. Инженерами завода разрабатывались уникальные монтажные, наладочные, пусковые, эксплуатационные методики, внедрялись автоматизированные системы управления производственными процессами. Так, отрабатывалась схема достижения наивысшей производительности центрифужного метода, позволявшая увеличивать эффективность разделения высокообогащенного урана-235 в 250-730 раз. Внедрение промышленных газовых центрифуг позволило нарабатывать оружей-ный уран более экономичным, чем ранее, способом.

Если бы центрифужный метод разделения изотопов урана был отработан в первые годы создания атомной промышленности СССР, потребовалось бы возводить не 13 атомных реакторов для получения плутония, а много меньше. Не было бы необходимости в создании многих отраслей радиохимической 2018. T. 19, № 1. C. 91-118 
промышленности. С 1960 г. до конца советского периода в стране было разработано несколько поколений газовых центрифуг при окружной скорости 400-500 м в секунду, которые могли работать без особого ремонта не менее 15 лет и увеличивать производительность по обогащению урана примерно в четыре раза. Реальная способность последней модели центрифуг примерно в 10 раз превышала первую разработку. Промышленное освоение центрифужного метода разделения изотопов урана, осуществленное в СССР впервые в мировой практике, стало крупным научно-техническим достижением страны. Этот метод позволял в 20-30 раз уменьшать расход электроэнергии, повышать в десятки раз коэффициент разделения урана в одной ступени по сравнению с применявшимся ранее диффузионным методом [9, с. 108-111].

Даже на людей, знакомых с оборонными «секретами» это производило впечатление. Министр атомной энергетики РСФСР В. Н. Михайлов, посетивший один из заводов, работавших на основе технологии газовых центрифуг, рассказывал, что «технология получения плутония, обработка этого очень токсичного материала делается в закрытых камерах. Недопустимо даже малейшее отклонение в технологии...На заводе по обогащению урана меня поразила чистота и порядок, и тишина! Никакого шума. А ведь в цехах стоят сотни тысяч центрифуг, и все они работают. Первое впечатление, что цех не действует. Но стоит положить руку на центрифугу, и ты чувствуешь её биение - работает. Центрифуга делает более тысячи оборотов в секунду, она будто живой организм. Это очень эффективный инструмент. Ну, а на заводах их миллионы штук! Разве это не поражает?!»².

Данными технологиями оснащались все комбинаты атомной промышленности СССР, в том числе и на-

${ }^{2}$ Цит. по [9, с. 113] 
ходящиеся в Сибири. В советский период они производили большую часть плутония и высокообогащенного оружейного урана.

С конца 1950-х гг. большой вклад в развитие экономики Сибири стало вносить Сибирское отделение Академии наук СССР, институты которого с начала организации свою деятельность соотносили с намерениями укреплять связь науки и производства. В 1978 г. был дан старт специальной программе «Сибирь», которая была нацелена непосредственно на нужды региона и обеспечение мероприятий научно-технического прогресса на сибирских предприятиях. Масштабы работ по программе особенно возросли в XI-XII пятилетках. В 1984 г. советское правительство признало программу «Сибирь» важнейшей долгосрочной программой государственного значения. Её научным руководителем был назначен академик А. А. Трофимук. Материалы, полученные в ходе работы над программой, стали шире использоваться при подготовке пятилетних планов и в качестве предложений и рекомендаций для внедрения в народном хозяйстве. Расчеты, выполненные сибирскими экономистами, доказывали, что опережающие темпы производственного развития региона способствуют повышению эффективности народного хозяйства СССР.

Успешный опыт работы по программе «Сибирь» позволил включить региональные научно-технические программы (РНТП) в качестве составной части в единую систему программно-целевого планирования в стране. РНТП стали директивно адресными документами, определяющими согласованные по ресурсам, исполнителям и срокам задания на проведение научных исследований, разработку научно-технических мероприятий, создания производственных мощностей в целях эффективного комплексного использования производительных сил Сибирского региона. Во второй половине 1980-х гг. в реализации программы 2018. T. 19, № 1. C. 91-118 
принимали участие более 700 организаций исполнителей, представляющих 93 министерства союзного и республиканского подчинения [5, с. 100-101].

Вместе с тем, несмотря на определенные успехи в развитии сибирской индустрии по пути научно-технического прогресса, с большим трудом решались проблемы комплексного развития предприятий, совершенствования их межотраслевых связей и взаимодействий. На всех важнейших форумах, посвященных развитию производительных сил Сибири, говорилось о необходимости производить специальную технику и оборудование для нужд региона, особенно для работы в зимнее время и на северных территориях. Однако это чаще всего являлось благими пожеланиями. Такой техники постоянно было недостаточно. В 1976 г. было принято решение советского правительства о строительстве в Красноярске завода по производству тяжелых экскаваторов, предназначенных для работы на угольных разрезах Сибири, в том числе и в связи с планами создания КАТЭКа. Первый экскаватор был сдан в эксплуатацию в декабре 1982 г. на вскрышном комплексе Ирша-Бородинского разреза. В 1990-е гг. «Красноярсктяжмаш» вынужден был как-то выживать в рыночных условиях и производство техники для региона было свернуто, хотя предприятие и до настоящего времени производит тяжелую горную технику и оборудование.

Не все отрасли наращивали темпы технического и технологического совершенствования в одинаковой мере. Значительные возможности для этого имели предприятия отраслей тяжелой промышленности и производства, связанные в той или иной степени с военно-оборонным комплексом СССР. Традиционно отставали легкая и пищевая промышленность Сибири, хотя некоторым крупным предприятиям этих отраслей в 1960-1980-е гг. также удалось значительно продвинуться вперед по пути научно-технического прогресса в сравнении с предыдущим периодом. Мно- 
гие предприятия легкой и пищевой промышленности были модернизированы, оснащены новой техникой и более производительным оборудованием. В этом отношении дальнейшее развитие получили Барнаульский меланжевый и Барнаульский хлопчатобумажный комбинаты, Иркутская обувная фабрика «Ангара», Читинская овчинно-меховая фабрика, Улан-Удэнский мясоконсервный комбинат и др. Только в Красноярском крае на предприятиях легкой промышленности было установлено в 1966-1970 гг. свыше 2500 единиц нового оборудования, внедрено 25 конвейерных линии. На Красноярском комбинате шелковых тканей старое оборудование полностью было заменено новыми высокопроизводительными станками. В результате улучшились условия труда, повысилась его производительность. Выпуск шелковых тканей возрос в несколько раз, достигнув в 1975 г. 63 млн пог. м. В результате капитального строительства, реконструкции промышленных предприятий, увеличения парка оборудования, замены устаревшего оборудования новым значительно возросли основные промышленно-производственные фонды легкой промышленности Сибири. За десятилетие (1971-1980 гг.) они увеличились в Кемеровской области в 5 раз, в Бурятской АССР - в 2 раза [8, с. 78].

Таким образом, на основе нашего исследования можно сделать следующие выводы. Во-первых, экономическое развитие Сибири в советский период было напрямую связано с индустриальной модернизацией, а во-вторых, происходило в соответствии со стратегическими целями, которые формировались в советском государственном управлении экономикой и социумом.

\section{Єписок использованной литературы}

1. Бикметов Р. С. Использование спецконтингента в экономике Кузбасса. 1929-1956 / Р. С. Бикметов. - Кемерово : Изд-во КГТУ. - 2009. - 430 с.

2. Долголюк А. А. Научно-технический прогресс на предприятиях и стройках Братско-Усть-Илимского ТПК 2018. T. 19, № 1. С. 91-118 
(1955-1980 гг.) / А. А. Долголюк / / Социально-экономические проблемы научно-технического прогресса в сибирской индустрии (1950-1980-е гг.) : сб. науч. ст. - Новосибирск : Наука, 1990. - C. 94-124.

3. Историческая энциклопедия Сибири. В 3-х т. / гл. ред. В. А. Ламин. - Новосибирск : Историческое наследие Сибири, 2009. - Т. 1 : А-И. - 715 с.

4. Историческая энциклопедия Сибири. В 3-х т. / гл. ред. В. А. Ламин. - Новосибирск : Историческое наследие Сибири, 2009. - Т. 2 : К-Р. - 807 с.

5. Историческая энциклопедия Сибири. В 3-х т. / гл. ред. В. А. Ламин. - Новосибирск : Историческое наследие Сибири, 2009. - Т. 3 : С-Я. - 783 с.

6. Кемеровская орденоносная. Статистический сборник / общ. ред. С. Н. Витковского. - Кемерово : Кн. изд-во. 1968. $152 \mathrm{c}$.

7. Комогорцев И. И. Промышленность и рабочий класс Сибири в период строительства коммунизма / И. И. Комогорцев. - Новосибирск : Наука, 1971. - 310 с.

8. История рабочего класса Сибири, 1961-1980 гг. / гл. ред. А. П. Окладников. - Новосибирск : Наука, 1986. - 355 с.

9. Савицкий И. М. Вклад оборонной промышленности Сибири в создание ракетно-ядерного щита СССР в годы «холодной войны». 1946-1965. / И. М. Савицкий. - Новосибирск : Сиб. кн. изд-во, 2011. - 352 с.

10. Тимошенко А. И. Рождение гиганта / А. И. Тимошенко. - Красноярск : Кн. изд-во, 1987. - 135 с.

11. Тимошенко А. И. Проекты социально-экономического развития Сибири в XX веке. Концепции и решения / А. И. Тимошенко. - Новосибирск : Сиб. науч. изд-во, 2007. - 288 с.

12. Тимошенко А. И. Стратегия сдвига производительных сил СССР на восток в годы послевоенных пятилеток (19461965) / А. И. Тимошенко. / / Иркутский историко-экономический ежегодник. 2015. - Иркутск, 2015. - С. 304-313.

13. Сибирский тыл в исторической динамике $\mathrm{XX}$ столетия. Теория и практика реализации идеи / А. И. Тимошенко [и др.]. - Новосибирск : Параллель, 2016. - 379 с.

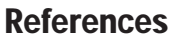

1. Bikmetov R. S. Ispol'zovanie spetskontingenta v ekonomike Kuzbassa. 1929-1956 [The use of inmates in the economy of Kuzbass. 1929-1956]. Kemerovo, Kuzbasskii gosudarstvennyi tekhnicheskii universitet Publ., 2009. 430 p. 
2. Dolgolyuk A. A. Scientific and technological progress in enterprises and the construction of the Bratsk-Ust-Ilimsk territorial production complex (1955-1980.). Sotsial'no-ekonomicheskie problemy nauchno-tekhnicheskogo progressa v sibirskoi industrii (19501980-e gg.) [Socio-economic problems of scientific and technological progress in the Siberian industry (1950s - 1980s.)]. Novosibirsk, Nauka Publ., 1990, pp. 94-124. (In Russian).

3. Lamin V. A. (ed.) Istoricheskaya entsiklopediya Sibiri [Historical Encyclopedia of Siberia]. Novosibirsk, Istoricheskoe Nasledie Sibiri Publ., 2009. Vol. 1. 715 p.

4. Lamin V. A. (ed.) Istoricheskaya entsiklopediya Sibiri [Historical encyclopedia of Siberia]. Novosibirsk, Istoricheskoe nasledie Sibiri Publ., 2009. Vol. 2. 807 p.

5. Lamin V. A. (ed.) Istoricheskaya entsiklopediya Sibiri [Historical encyclopedia of Siberia]. Novosibirsk, Istoricheskoe nasledie Sibiri Publ., 2009. Vol. 3. 784 p.

6. Vitkovskii S. N. (ed.) Kemerovskaya ordenonosnaya. Statisticheskii sbornik [Decorated with an order of Kemerovo. Statistical compendium]. Kemerovo, Knizhnoe izdatel'stvo Publ., 1968. 152 p.

7. Komogortsev I. I. Promyshlennost' i rabochii klass Sibiri v period stroitel'stva kommunizma [Industry and working class of Siberia during the building of communism]. Novosibirsk, Nauka Publ., $1971.310 \mathrm{p}$.

8. Okladnikov A. P. (ed.) Istoriya rabochego klassa Sibiri, 1961$1980 \mathrm{gg}$. [The history of the working class of Siberia, 1961-1980.]. Novosibirsk, Nauka Publ., 1986. 355 p.

9. Savitskii I. M. Vklad oboronnoi promyshlennosti Sibiriv sozdanie raketno-yadernogo shchita SSSR v gody «kholodnoi voiny». 1946-1965 [Contribution of the Siberian defense industry to the creation of the USSR nuclear missile shield during the cold war. 1946-1965]. Novosibirsk, Sibirskoe knizhnoe izdatel'stvo Publ., 2011. 352 p.

10. Timoshenko A. I. Rozhdenie giganta [Birth of a giant]. Krasnoyarsk, Knizhnoe izdatel'stvo Publ., 1987. 135 p.

11. Timoshenko A. I. Proekty sotsial'no-ekonomicheskogo razvitiya Sibiri $v$ XX veke. Kontseptsii i resheniya [Projects of social and economic development of Siberia in the $20^{\text {th }}$ century. Concepts and solutions]. Novosibirsk, Sibirskoe nauchnoe izdatel'stvo Publ., 2007. 288 p.

12. Timoshenko A. I. The productive forces shift strategy of the USSR in the East during the postwar five-year plans (1946-1965). Irkutskii istoriko-ekonomicheskii ezhegodnik. 2015 [Irkutsk Historical and Economic Yearbook. 2015]. Irkutsk, Baikal State University of Economics and Law Publ., 2015, pp. 304-313. (In Russian). 
13. Timoshenko A. I., Vvedenskii V. V., Isupov V. A., Laperdin V. B., Romanov R. E. Sibirskii tyl v istoricheskoi dinamike XX stoletiya. Teoriya i praktika realizatsii idei [Siberian homefront in the historical dynamics of the $20^{\text {th }}$ century. Theory and practice of realization of the idea]. Novosibirsk, Parallel' Publ., 2016. 379 p.

\section{Инорормация об авторе}

Тимошенко Альбина Ивановна - кандидат исторических наук, старший научный сотрудник, сектор истории социально-экономического развития, Институт истории СО РАН, 630090, г. Новосибирск, ул. Николаева, 8, e-mail: timoshenkoai@ngs.ru.

\section{$\$ 7$}

Albina I. Timoshenko - PhD in History, Senior Researcher, Socio-Economic Development History Sector, Instituteof History of the Siberian Branch of RAS, 8, Nikolaev str., Novosibirsk, 630090, Russian Federation, e-mail: timoshenkoai@ngs.ru.

\section{Для цитирования}

Тимошенко А. И. Экономическое развитие Сибири как результат государственной стратегии, направленной на индустриальную модернизацию СССР // Историко-экономические исследования. - 2018. - Т. 19, № 1. - С. 91118. - DOI: 10.17150/2308-2588.2018.19(1).91-118.

\section{DT:4}

Timoshenko A. I. Economic Development of Siberia as the Result of State Strategies Aimed at Industrial Modernization of the USSR. Istoriko-ekonomicheskie issledovaniya = Journal of Economic History $\&$ History of Economics, 2018, vol. 19, no. 1, pp. 91-118. DOI: 10.17150/2308-2588.2018.19(1).91-118. (In Russian). 